\title{
LANDSCAPE PLANNING AS AN ASSET FOR REGIONAL DEVELOPMENT IN LATVIA
}

Margarita Volosina, Msc. Spatial Planning; Anita Zarina, Dr.geogr., Docent; Olgerts Nikodemus, Dr.geogr., Professor; Ivo Vinogradovs, Msc.geogr., Researcher University of Latvia, Faculty of Geography and Earth Sciences

\begin{abstract}
In Latvia sustainable development strategies of all five planning regions acknowledges landscape planning as an asset for regional sustainability. Moreover, there are now various frameworks that can promote landscape planning, the most important of them are the National Landscape Policy and the thematic plan framework. Therefore, landscape aspects in territorial planning from a mere landscape description as part of territorial characterization have shifted into more integrative and functional part of territorial planning process. Yet, landscape planning is still a marginal activity in Latvia. This paper aims to analyse and expand challenging issues around the elaboration of landscape plans as part of territorial planning processes in Latvia through legislative framework and planning analysis. We reviewed the three most recent landscape planning cases, discussing different planning situations in the context of European Landscape Convention and territorial planning in Latvia. Three planning situations are distinguished: landscape thematic plan as a policy and landscape assessment document, landscape thematic plan as an assessment and the recommendation document, and landscape assessment as part of territorial plan. All three approaches show integrity with territorial planning and reveal the benefits for sustainable territorial planning and regional development, however they still lack the locals' participation aspects, as well as the focus on ordinary landscapes, social capital and land economics.
\end{abstract}

Key words: landscape planning, territorial planning, thematic plans, regional development.

JEL code: Q01, Q56, O21

\section{Introduction}

The European Landscape Convention (ELC) (Council of Europe, 2000), ratified in Latvia a decade ago, recognises landscapes as a key element of individual and joint well-being and highlights three main actions to be taken towards sustainable landscapes - protection, management and planning. However, to compare with western European countries, where landscape planning has long traditions (Sala P. et. al, 2014) and nowadays is an important component of spatial planning, and of particular interest to policy makers as economic values of landscapes can be estimated (Tagliafierro C. et al, 2013) through the approach of ecosystem services, Latvia still lacks national methodological guidelines, as well as interest from planners, municipal and regional authorities. However, there are now various frameworks that can promote landscape planning: the Landscape Policy Guidelines (LPG) (Vides aizsardzibas un ..., 2013), few methodological guidelines for landscape planning at local scale (Vides aizsardzibas un ... 2000, Dabas aizsardzibas parvalde, 2014), but most importantly, thematic plan framework (Saeima, 2011a) that legitimizes a direct link between landscape planning, territorial planning and sustainable development. Furthermore, although regional sustainable development strategies encourage municipalities to consider the landscapes as broader socio-economical human empowerment (Vides aizsardzibas un ..., 2017), landscape planning is still a marginal activity in Latvia. This paper aims to analyse and expand challenging issues around the elaboration of landscape plans as part of territorial planning processes in Latvia. To do so (1) landscape planning in Latvia was overviewed in the context of ELC and territorial planning, (2) three recent rural landscape plans were reviewed, (3) the main findings were discussed and, in conclusion, the necessity for elaboration of methodological guidelines for landscape planning is substantiated. Regarding the first two tasks, literature, qualitative content analysis of planning documents, interviews with territorial planners and landscape experts were conducted. For the reviewing of the landscape plans, methodological framework of La Riccia (La Riccia L., 2017) was used. 


\section{The landscape planning practice in Latvia within the framework of ELC}

Latvia, by full ratification of European Landscape Convention in 2007, joined growing European recognition of landscapes being everywhere and holding the meanings and values, whenever being superior or mundane. The Landscape Policy Guidelines, which followed ratification of the ELC, defined major problematic aspects related to landscape planning and management, as well as gave possible solutions in both the regulatory framework and legislation, and in education and practical actions (Vides aizsardzibas un ..., 2013). Furthermore, the LPG attempts to bring together various institutions that hold mandates related to landscape management, planning or protection due to their sectoral or thematic relevance: e.g., the Ministry of Culture is responsible for historical and cultural monuments (Nitavska N., Zigmunde D., 2017).

According to the LPG, the municipal level faces the primary challenges of legislative and mandatory overlaps and inflexibility resulting in contradictions and conflicts. As in many countries (Voghera A., 2011, Sala P. et al., 2014), spatial planning in relation to the development of landscapes is an outright framework for identification of conflicts and frictions of various interests as well as their subsequent balancing through deliberative processes. Hence, the LPG emphasises that assessment, evaluation and general landscape planning must be performed prior and in close relation to territorial planning.

Also, the Sustainable Development Strategy of Latvia (Saeima, 2011b), as a reasonable solution for acknowledged tendencies and challenges of environmental changes, emphasizes the development of thematic planning, including landscape planning as part of the territorial planning process.

\section{Landscape and territorial planning framework}

Lately, there has been a shift of the landscape agenda in territorial planning in Latvia - from a mere landscape description as part of a territorial characterization to more integrative and functional part of territorial planning process. One of the key reasons for that is the recently amended Spatial Development Planning Law (Saeima, 2011a), which through a framework of thematic plans enables municipalities to develop specific planning documents for solving specific issues according to the planning level.

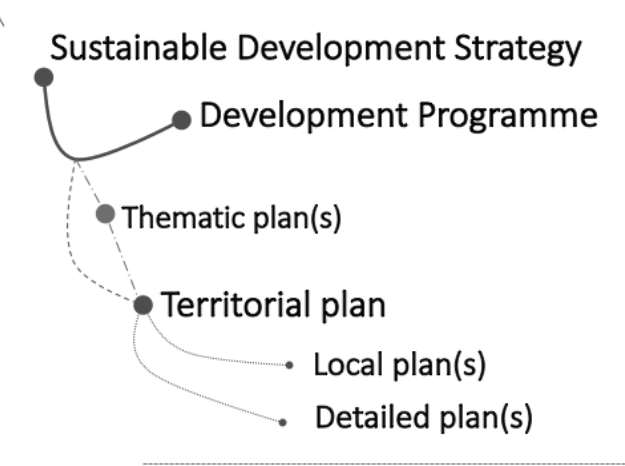

Source: author's elaboration

Fig. 1. Interrelation (hierarchy, sequence and sequence options) of development documents at the municipal level

So far, less than ten of 119 Latvia's local municipalities (including the City of Riga) have elaborated landscape thematic plans (LTP) (Vides aizsardzibas un ..., 2017). Although thematic plan is not a binding document per se, it potentially can have an impact on territorial plans and building 
regulations (Figure 1). Furthermore, the General Regulations for the Planning, Use and Building of the Territory (Cabinet of Ministers, 2013) specifies that local authorities, through the prior and expert lead assessment procedures, might determine valuable landscape areas as areas with special and binding conditions. However, local municipalities rarely employ such options.

Yet, even non-binding landscape thematic plans would mean at least holistic territorial assessment and identification of landscapes, as well as definition of landscape quality objectives (LQO). While various place-bound solutions for the development of specific landscapes can be legitimised later through territorial plans (and building regulations) or local plans (Figure 1). The framework of local plans is suitable for landscape evaluation, when proposed or anticipated landscape changes (e.g., in functional character that might affect the wellbeing and movement of people) are about to take place. Landscape evaluation within a local plan could entail a detailed scope of judgements and estimations about values within the landscapes, impact of potential changes and their compliance with LQO.

\section{Research results and discussion}

Three different cases (including maps, see Figure 2) of local landscape planning practice in Latvia were analysed basing on three perspectives (La Riccia L., 2017): (1) the reason of the plan focuses on the objectives of the plan in context of the territorial planning and outlines the basic features of the planning instruments. It includes the analysis of the methods, the tools and the techniques used; (2) the interpretation of the landscape aims at understanding the conceptual framework of landscape analysis in the plans; (3) the actions towards the landscape focuses on the analysis of the recommendations proposed in the planning documents.

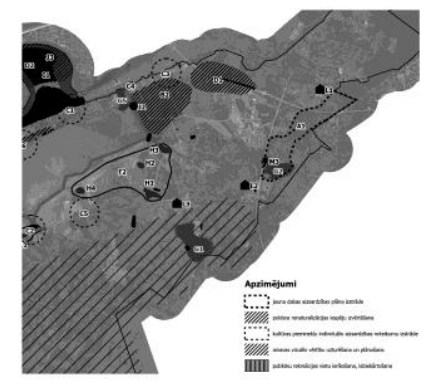

a) Landscape planning recommendations (the LTP) source: a) Babites novada dome

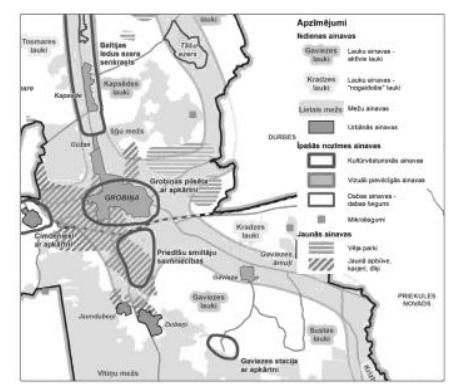

b) Landscape Plan (the LTP)

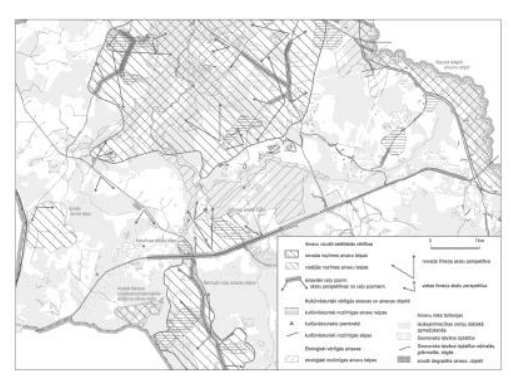

c) 'Territories with specific regulations' (the Territorial Plan)

dome, 2016; b) Grobinas novada dome, 2013; c) Cesu novada dome, 2016

Fig. 2. The fragments of the landscape plans

\section{Landscape thematic plan of Babite municipality}

Reason of the plan. Babite municipality is a territory neighbouring Riga and in the last decades it has become a hotspot for various rapid developments - mainly due to the suburbanization processes that have resulted in population growth, land use transformation and housing developments. Until now, development processes were occurring rather incoherently, in lines with the liberal politics and market values, that is, in most cases without the territorial and landscape contexts, which has led to accumulation of conflict issues between various stakeholders. Thus, it was important to direct the developments of the territory in a more coherent way through the thematic planning that implied the in-depth analysis of current situation. Along with the landscape plan (Babites novada dome, 2016), thematic plans for settlement and public space, amelioration 
and infrastructures were carried out as a subsequent basis for the new territorial plan (elaboration started in the end of 2016).

The main objectives of the LTP were to identify the main landscape units and to define their characteristic elements, as well as to identify valuable places and territories that have a potential for tourism and recreational development. The main tasks also included the mapping and characterization of protected areas and historical monuments, and the analysis of accessibility to public waters. Identification and assessment of the landscapes was performed by a group of landscape experts, without locals' involvement, except for the official consultations of the public in the final phase of the planning process. The main methods used included the identification and mapping of landscape features based on field surveys, expert interviews (also collaboration between experts of other thematic plans) and various analyses of documents.

The interpretation of the landscape. The landscape was conceptualized along with the framework of ELC, putting the emphasis on the characterization of landscape units identified as unique landscapes and as landscape types. Each of the landscape units were characterized by its social function and location, historical development, current landscape processes, values and important elements and conflicting areas and risks. Landscape values and risk areas were identified from historical, scenic and ecological perspectives. In addition, the landscape transformation processes were also analysed (Figure 2, a).

The actions towards the landscape. The recommendations that were proposed and explicitly described by the LTP experts were directly related to assessed situations and implied specific immediate tasks, as well as recommendations for further landscape assessments. Clearly, such recommendations represent the expert view on various values, landscape change processes, neglected places and landscapes, conflict areas (especially in relation to housing developments and nature protection interests). The plan also emphasizes the need for elaboration of LQO for each of the identified landscape units, through the involvement of locals, as a further task in the planning process of the landscape.

\section{Landscape thematic plan of Grobina municipality}

Reason for the plan. Grobina municipality represents the more or less typical rural landscape of Latvia with large field and forests patches and dispersed settlements with land use intensification processes, including wind farm landscape developments, around Grobina town.

The LTP for Grobina municipality (Grobinas novada dome, 2013) was elaborated basing on the preceding project on municipalities' long-term development plan (2012), which implied the study of landscape history and the analysis of the spatial structure of landscapes. Along with the LTP (20142030), the territorial plan (2014-2025) and the long-term development strategy (2014-2030) were elaborated. In this case, the LTP is a local policy document that implies its implementation along with the long-term development strategy. The aims of this policy document are as follows: (1) to integrate the issues of landscape protection, planning and governance into larger frameworks of planning processes and strategies, (2) to strengthen the local landscapes' identity, (3) to create a landscape database, (4) to enhance heritage preservation and development of landscapes and (5) to elaborate a procedure for the implementation of the landscape plan.

Besides the policy aspects, the LTP contains the study of municipality's landscapes, which was carried out by a landscape expert, having the official public consultations according to the legislative order. The main methods used include the in-depth interpretation of landscape structure 
and processes, and mapping of the main landscape features, based on field surveys, analysis of documents and collaboration with territorial planners.

The interpretation of the landscape. Landscape interpretation here grounds the notion that a landscape is the result of ongoing human/nature interaction (ELC context), emphasizing the importance of history and the dynamic character of landscapes. It discusses territorial landscape units, the main use of the landscapes (as a result of human activities), scenic landscapes, risk areas, a settlement pattern and forest distribution. The synthesis of the analysis results in the Landscape Plan (Figure 2, b) wherein 'everyday landscapes' (rural, urban and forest areas), 'landscapes of special importance' (historic, scenic, nature protection areas) and 'new landscapes' (windfarms, new settlement areas) are identified.

The actions towards the landscape. As an essentially political document, the LTP for Grobina municipality is interwoven with conceptual explanations of further developments of landscapes and recommendations for further actions. It indicates that the most urgent action is the elaboration of local plans (or 'conceptual thematic plans' through the involvement of the locals) for the identified 'landscapes of special importance'. In the end, the particular tasks for the implementation of the Landscape Plan and its governance are listed: the need for coordination, a consultative committee, a popular science publication, binding regulations, a monitoring system, methodological recommendations, and events for public involvement.

\section{Landscape plan of Cesis municipality}

Reason of the plan. Cesis municipality, of which the largest part is the Gauja National Park, has high biodiversity and landscape values; therefore, it is listed among the most popular recreation destinations in Latvia. The elaboration of the landscape plan for the rural area of Cesis municipality has two stages. The first stage, as part of the municipality's territorial plan (2016-2026) (Cesu novada dome, 2016), aimed at defining landscape values and risks, the second is directed towards maintenance and preservation of assessed values and maintenance and elimination of detected risks. The second stage is part of the ongoing VivaGrass project (Integrated planning tool ..., 2018) that aims at enhancing landscape values through the ecosystem services (ES) approach, elaborated in the integrated planning tool - the VivaGrass Tool - the decision support system capable of analysing ES bundles, trade-offs and synergies, cold/hot spots for supply potential of the ES and deriving management prioritization, biomass potential and economic evaluation of agricultural practices and land-uses. In both stages, landscape assessment was done by experts, using various methods and techniques, among them the analysis of high-resolution remote sensing data with subsequent field verification. Local knowledge and opinions of inhabitants were collected through questionaries' done by the local municipality and the public discussion round tables as part of the VivaGrass project.

The interpretation of the landscape. The landscape here is considered from perspectives of cultural heritage (historical settlements), aesthetical (mainly scenic views) and ecological (e.g., High Natural Value grasslands, ecological forests, nature micro-reserves and salmon spawn river valleys) values, as well as risks that include farmland abandonment, degraded sites and invasive distribution of Giant Hogweed species. All in all, it follows the context of ELC, particularly from the perspectives of values, management, perceptions and preferences of locals, but the plan also implies landscape interpretations from the point of view of landscape ecology. 
The actions towards the landscape. Since the Landscape Plan for Cesis municipality was an integral part of the territorial plan, and not a separate document, it has no specific recommendations for landscape management, preservation and governance. Except for the development programme, wherein actions toward the maintenance of scenic views are mentioned. However, the assessed landscape value areas in the territorial plan are legitimized as 'territories with specific regulations' that imply particular conditions for any further transformation of these areas (Figure 2, c). Whereas the outcomes of the second phase of the landscape planning process (VivaGrass project's framework) intend the elaboration of Landscape management plan through two decision support sub-systems - landscape maintenance (based on supply of aesthetical, recreational, historical and educational ES, and various risks) and hogweed elimination.

\section{Imperatives, restraints and challenges for landscape planning}

Landscape planning, as Antrop and Van Eetvelde (Antrop M., Van Eetvelde V., 2017) notes, "can only be done indirectly through spatial planning by those who possess the stimulating and regulating competencies". In Latvia, this conjunctive link, although without obligations, is now the thematic planning framework that opens a possibility to start territorial planning process at a landscape level thus emphasizing the important integrity of history, ecology, land economics etc. According to Selman (Selman P. , 2006), that would mean planning for and through landscape. Yet, at large, landscape planning in Latvia, as the analysed cases show, is still subjected to the very particular landscape aspects (as in planning 'for landscape') defined by experts, such as historical, ecological and scenic values (often already acknowledged beforehand), that result in landscape plans focusing on 'landscapes of particular importance'. Certainly, these aspects are essential in landscape planning (usually they are the sole expectations from municipalities), but as the ELC recognizes landscapes that are also ordinary or ruined, it is necessary that the landscape quality assessment and planning should be carried out for the so-called everyday landscapes through stakeholders' involvement as well. Such a planning practice can only be possible if landscape plans (defined landscapes guidelines) could influence the multiple stakeholders that act upon the territory, touching the questions of social capital, local and regional economic developments. And apparently, the Cesis Landscape management plan could be one of the first examples of it in Latvia.

\section{Conclusions}

1) The case study analysis showed that there are at least three situations in planning a landscape in rapport with territorial planning. Firstly, there is the LTP as a policy document (Grobina case) that implies characterization of landscapes and guidelines for further actions; the second, LTP as a specific set of objectives that are aimed at solving particular demands of a municipality: hence, the example of LTP for Babite, whose primary aim is to improve the opportunities for the recreational use through landscape analysis; and the third situation (Cesis case), which shows that some landscape related questions, e.g., the designation of valuable landscapes as 'territories with specific regulations', can be done without the elaboration of the LTP.

2) Assessment and sustainable planning of landscapes at municipal level is an important asset for sustainable regional development. The analyzed cases represent different situations where supra-local challenges (intensive suburbanization processes, the hogweed invasion, new landscapes of windfarms and marginalization processes) have specific local impacts and need 
place-bound objectives and measures in planning processes to contribute to the regional development.

3) Landscape planning practice in Latvia still lacks the participation of the local stakeholders, especially for defining landscape objectives and measures to achieve them.

4) The framework of thematic planning is indeed a necessary link that connects planning with landscape and legitimizes landscape planning as a potentially essential part of territorial planning. It is especially so, if the LTP, besides the landscape assessment and immediate recommendations, implies the policy aspects and serves as part of a programme for long-term territorial and regional development.

5) To facilitate the development of landscape planning in Latvia, methodological guidelines at local and regional level, which would consider the ELC context, Latvia's planning traditions and would comprise the best-case examples, would clearly state and explicate the benefits of the LTP for municipalities and regions, are necessary.

\section{Bibliography}

1. Antrop, M., Van Eetvelde V. (2017). Landscape Perspectives, The Holistic Nature of Landscape. Landscape Series 23, p. 446.

2. Babites novada dome (2016). Babites novada ainavu strukturas tematiska planojums (Landscape Thematic Plan for Babite Municipality). Retrieved: http://www.babite.Iv/lv/par-babites-novada-ainavu-strukturastematiska-planojuma-apstiprinasanu/ Access: 01.02.2018.

3. Cabinet of Ministers (2013) General Regulations for the Planning, Use and Building of the Territory. Regulations Nr. 240 (30.04.2013.) Retrieved: https://likumi.Iv/ta/en/id/256866-general-regulations-forthe-planning-use-and-building-of-the-territory Access: 01.02.2018.

4. Cesu novada dome (2016). Cesu novada teritorijas planojuma 2016.-2026. gadam (Territorial Plan for Cesis municipality (2016-2026)). Retrieved: http://www.cesis.Iv/lv/publiskie-dokumenti Access: 01.02.2018.

5. Council of Europe (2000). European Landscape Convention. Retrieved: http://conventions.coe.int/Treaty/en/Treaties/Html/176.htm Access: 01.02.2018.

6. Dabas aizsardzibas parvalde (2014). Vadlinijas dabas aizsardzibas plana integresanai teritorijas planojuma (Guidelines for Integration of Nature Protection Plan in Territorial Plan). Retrieved: https://www.daba.gov.Iv/upload/File/DOC/Vadlinijas_DApl-integr-TApl.pdf Access: 01.02.2018.

7. Grobinas novada dome (2013). Grobinas novada Ainavu plans 2014.-2030.gadam (Landscape Plan for Grobina Municipality (2014-2030)). Retrieved: http://www.grobinasnovads.Iv/index.php?option=com_content\&view=category\&layout=blog\&id=238\&Itemi $\mathrm{d}=280$ Access: 01.02 .2018

8. Integrated Planning Tool to Ensure Viability of Grasslands (LIFE Viva Grass) (2018). Retrieved: https://vivagrass.eu Access: 01.02.2018.

9. La Riccia, L. (2017). Landscape Planning at the Local Level. Springer International Publishing. p 176

10. Nitavska, N., Zigmunde, D. (2017). Legislative Framework for Landscape Planning in Latvia. IOP Conf. Ser.: Mater. Sci. Eng. 245. Retrieved: http://iopscience.iop. org/article/10.1088/1757-899X/245/6/062033 Access: 01.02.2018.

11. Saeima (2011a) Spatial Development Planning Law. Retrieved: https://likumi.lv/ta/en/id/238807-spatialdevelopment-planning-law Access: 01.02.2018.

12. Saeima (2011b). Sustainable Development Strategy of Latvia until 2030. Retrieved: http://www.varam.gov.Iv/in_site/tools/download.php?file=files/text/dokumenti/pol_doc//LIAS_2030_parluk s_en.pdf Accessed: 01.02.2018.

13. Sala, P. , Puigbert, L., Bretcha, (Eds.) (2014). Landscape Planning at a Local Level in Europe. Olot: Landscape Obser vatory of Catalonia; Government of Andorra, p 128

14. Selman, P. (2006). Planning at the Landscape Scale. London, Routledge

15. Tagliafierro, C., Longo, A., Van Eetvelde, V., Antrop, M., Hutchinson, WG (2013). Landscape Economic Valuation By Integrating Landscape Ecology Into Landscape Economics. Environmental science \& policy 32, p 26-36

16. Vides aizsardzibas un regionalas attistibas ministrija (2000). Ainavu aizsardziba (Landscape Protection), Riga, p. 92.

17. Vides aizsardzibas un regionalas attistibas ministrija (2013). Ainavu politikas pamatnostadnes 2013.2019.gadam (Landscape Policy Guidelines 2013-2019). Retrieved: http://www.varam.gov.Iv/lat/lidzd/sab_aps/?doc=15713 Access: Access: 01.02.2018.

18. Vides aizsardzibas un regionalas attistibas ministrija (2017). Parskats par ainavu planosanas aspektiem pasvaldibas (Overview of Landscape Planning Aspects in Municipalities). Retrieved: http://www.varam.gov.Iv/lat/darbibas_veidi/tap/ain_pol/?doc=12902 Access: 01.02.2018. 
Proceedings of the 2018 International Conference "ECONOMIC SCIENCE FOR RURAL DEVELOPMENT" No 48

Jelgava, LLU ESAF, 911 May 2018, pp. 276-283 DOI 10.22616/ESRD.2018.095

19. Voghera, A. (2011). After the European Landscape Convention. Policies, Plans and Evaluation. Alinea Editrice, p. 129 